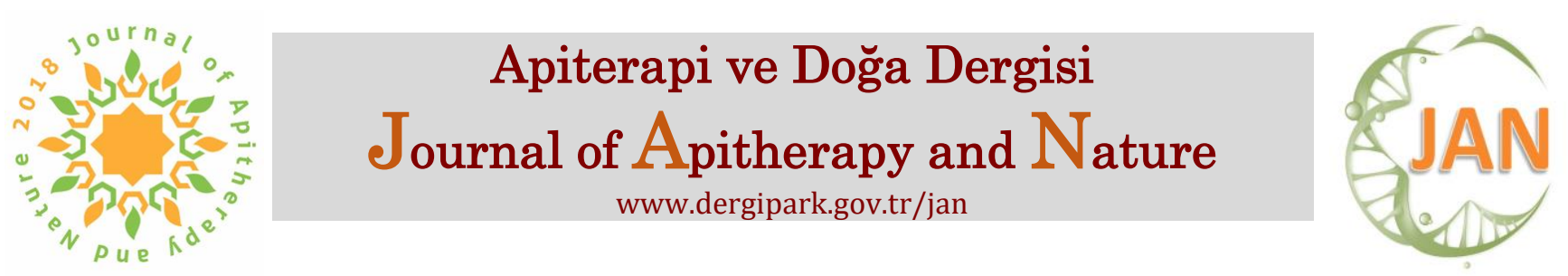

\title{
Phenolic Composition of Pine (Pinus spp.) Honey from Turkey
}

\section{Türkiye'den Elde Edilen Çam (Pinus spp.) Balının Fenolik Bileşimi}

\author{
Yakup KARA ${ }^{1 *}$ \\ ${ }^{1}$ Department of Biochemistry, Faculty of Science, Karadeniz Technical University, Trabzon, Turkey. \\ *yaakupkara@gmail.com, ORCID: 0000-0003-3121-5023
}

Received/Geliş Tarihi: 10/04/2020, Accepted/ Kabul Tarihi: 21/04/2020

*Corresponding author /Yazışılan yazar

doi: $10.35206 /$ jan. 718032

e-ISSN: $2667-4734$

\begin{abstract}
In this study, the phenolic component of pine honey which is a secretion honey type were studied. Total polyphenol content and total flavanoid contents of the pine honeys were ranged from 30 to $52 \mathrm{mg} \mathrm{GAE} / 100 \mathrm{~g}$ and 0.86 to $1.58 \mathrm{mg} \mathrm{QE} / 100 \mathrm{~g}$, respectively. The phenolic composition of the honeys were analyzed by HPLC-UV assay with $\mathrm{C}_{18}$ column. The honey was found to be rich in protocatehuic acid, chrysin, caffeic acid phenyl ester, p-OH benzoic acid, catechine, luteolin and gallic acid.
\end{abstract}

Keywords: Honey, Pine, Phenolic Component, Anatolia, Turkey

Abbreviations: TPC, Total phenolic content; TFC, total flavonoid content; GAE, gallic acid equivalent; QE, quercetin equivalents.

\section{Özet}

$\mathrm{Bu}$ çalışmada, bir salgı balı olan çam balının fenolik bileşenleri incelendi. Balların toplam polifenol içeriği ve toplam flavanoid içeriği sirasiyla 30 ile $52 \mathrm{mg} \mathrm{GAE} \mathrm{/} 100 \mathrm{~g}$ ve 0.86 ile $1.58 \mathrm{mg}$ QE / $100 \mathrm{~g}$ arasında olduğu görüldü. Balların fenolik bileşimi, HPLC-UV ile analiz edildi. Balların protokatekuik asit, krisin, kafeik asit fenil ester, p-OH benzoik asit, kateşin, luteolin ve gallik asit bakımından zengin olduğu bulundu.

Anahtar kelimeler: Bal, Çam, Fenolik Bileşen, Anadolu, Türkiye

\section{INTRODUCTION}

According to the sources of produced honey, there are two different types of honey as blossom and secretion. Blossom (flower) honeys are collected by honey bees (Apis mellifera) from flower nectars, and are the most produced honey species in the world. Secretion honeys are secreted not from flowers of plants, but only from leaves and trees with sugar containing stem. Honey bees are generally produced honey in two different ways. One of them is the production from the insects that live on trees as parasites such as pine honey. The other way is the secreted from the trees by sweating depending on the weather such as oak and cedar honeys (Kara, Can \& Kolayl1, 2019; 
Kolayli, Can, Çakir, Okan \& Yildiz, 2018; Özkök \& Silici, 2017). While pine honey is the most produced in Turkey, other Mediterranean countries such as Greece, Italy, Spain, and Portugal are also less produced. It has a relatively dark colored, turbid appearance, and characteristic smell and aroma. Also, pine honey is not easily crystallized (Can et al. 2015).

Polyphenols are secondary metabolites of plants and have many biological values such as anti-oxidant, anti-microbial, anti-inflammatory, antiviral, anti-repellent and anti-tumoral etc. (Bahramsoltani, et al. 2019; Joseph, Edirisinghe \& Burton-Freeman, 2016). Polyphenols are the most important secondary metabolites of honeys and they are also responsible many characteristic features of honeys such as color, aroma, taste and biological activity.

In the literature, the studies with the polyphenols of pine honey are very limited. The aim of this study was determined the phenolic composition and phenolic markers of the pine honeys from Mugla region of Turkey.

\section{MATERIAL AND METHODS}

Ten pine honey samples were collected in Mugla around of near the Aegean Sea of Turkey in October, 2018. Physicochemical properties (moisture content, optical rotation, $\mathrm{pH}$ ) and phenolic compounds and contents of honey samples were determined.

\subsection{Physicochemical Properties}

Moisture contents of these samples were measured by refractometer method (Atago, Tokyo, Japan). Optical rotation of the samples were measured by polarimetry (BetaPPP7, England).

2.2. Preparation of samples extraction for antioxidant analysis and phenolic compounds

For determination of total phenolic content, ethanolic extracts of honey samples were used. 10 $\mathrm{g}$ of honey was extracted using $90 \%$ ethanol solvent for 24 hours at room temperature using a shaker (Heidolph Promax 2020, Schwabach, Germany). After incubation, extracts were filtered with Whatmann No: 4 filter paper and stored at $4^{\circ} \mathrm{C}$ for further analysis. Extracts were divided into two parts. The first part for antioxidant tests and the second part are for phenolic component analysis.

\subsection{Total Phenolic Content Determination}

Total phenolic content was measured by Folin Ciocalteu method (Singleton, Orthofer \& Lamuela-Raventós, 1999). Firstly, $680 \mu \mathrm{L}$ pure water, $20 \mu \mathrm{L}$ of honey ethanolic extract and $400 \mu \mathrm{L}$ $0.5 \mathrm{~N}$ Folin-Ciocalteu reagent were mixed, and vortexed. Then, $400 \mu \mathrm{L}$ of $\mathrm{Na} 2 \mathrm{CO} 3(10 \%)$ was added into the tubes. After vortexing, the mixture was incubated for $2 \mathrm{~h}$ at $20^{\circ} \mathrm{C}$ with shaker. For calibration curve of gallic acid standard, different concentrations of gallic acid solution were prepared with the same analysis procedure. The reaction using the intensity of the blue color at 760 $\mathrm{nm}$ in spectrophotometer was read and the results 
were expressed as $\mathrm{mg}$ gallic acid equivalent (GAE) / 100 g. All the measurements were performed in triplicate.

\subsection{Total Flavonoid Determination}

For determination of total flavonoid substance, Fukumoto and Mazza (2000)' method was used with using quercetin standard (Fukumoto and Mazza, 2000). Firstly, $0.5 \mathrm{~mL}$ of the samples, 0.10 $\mathrm{mL}$ of $10 \% \mathrm{Al}\left(\mathrm{NO}_{3}\right)_{3}$ and $0.10 \mathrm{~mL}$ of $1 \mathrm{M}$ $\mathrm{NH}_{4} \cdot \mathrm{CH}_{3} \mathrm{COO}$ was added to reaction mixture. This mixture was incubated at room temperature for 40 min and the absorbance was measured against a blank at $415 \mathrm{~nm}$. Quercetin $(0.03125-1 \mathrm{mg} / \mathrm{mL})$ was used as a standard to obtain the calibration curve. The total flavonoid content (TFC) was calculated as $\mathrm{mg}$ of quercetin equivalents (QE)/100 g honey.

\subsection{Analysis of Phenolic Components by RP-HPLC-UV}

Phenolic composition of the honey was determined in RP-HPLC-UV. For this purpose, a calibration curve was prepared in the study using 19 phenolic standards and phenolic compositions of the samples were determined according to these curve values. Gallic acid, syringic acid, p-OH benzoic acid, ferulic acid, caffeic acid, t-cinnamic acid, p-coumaric acid, catechin, epicatechin, rutin, daidzein, myricetin, luteolin, hesperetin, chrysin, pinocembrin, protocatechuic acid, caffeic acid phenethyl ester, resveratrol were used as phenolic standards.

The ethanolic extracts of honey samples were evaporated until dryness in a rotary evaporator at $40^{\circ} \mathrm{C}$. The residue was dissolved in $15 \mathrm{~mL}$ acidified distilled water $(\mathrm{pH} 2)$. Liquidliquid extraction was carried out with $5 \times 3 \mathrm{~mL}$ diethyl ether and $5 \times 3 \mathrm{~mL}$ ethyl acetate, consecutively (Kim, Tsao, Yang \& Cui, 2006). Both diethyl ether and ethyl acetate phases were pooled and evaporated by rotary evaporation (IKA-Werke, Staufen, Germany) at $40^{\circ} \mathrm{C}$. The pellet was suspended in $2 \mathrm{~mL}$ ethanol, filtered with syringe filters (RC membrane, $0.45 \mu \mathrm{m}$ ), and injected to HPLC.

HPLC (EliteLaChrom Hitachi, Japan) with UV detector was used for analysis and conducted by reverse phase $\mathrm{C} 18$ column $(150 \mathrm{~mm} \times 4.6 \mathrm{~mm}$, $5 \mu \mathrm{m}$; Fortis). It was carried out by applying a gradient program with acetonitrile, water and acetic acid. (Malkoç, Çakır, Kara, Can \& Kolaylı, 2019b).

For HPLC analyses, the mobile phase (A) and (B) consisted of $2 \%$ acetic acid in water and acetonitrile: water (70:30), respectively. The sample injection volume was $20 \mu \mathrm{L}$, the column temperature was $30^{\circ} \mathrm{C}$ and the flow rate was 0.75 $\mathrm{mL} / \mathrm{min}$. Using of the programmed solvent began with a linear gradient held at $95 \%$ A for $3 \mathrm{~min}$, decreasing to $80 \% \mathrm{~A}$ at $10 \mathrm{~min}, 60 \% \mathrm{~A}$ at $20 \mathrm{~min}$, $20 \% \mathrm{~A}$ at $30 \mathrm{~min}$ and finally $95 \% \mathrm{~A}$ at $50 \mathrm{~min}$. Three injections were used for each sample. All calibration values for phenolic components are between 0.998 and 0.999 (Çakir, Şirin, Kolayli \& Can, 2018). 


\section{RESULTS AND DISCUSSION}

Specific optical rotation, moisture content, and $\mathrm{pH}$ value of the samples was given in Table 1. Optical rotation value is an important distinguishing feature for flowers and honey (Dinkov, 2003; Serrano, Rodríguez, Moreno \& Rincón, 2019). Honeydew (such as pine and oak honey etc.) optical rotation is dextrorotary, while blossom honey is laevorotary (Cavrar, Yildiz, Sahin, Karahalil \& Kolayli, 2013). It was determined that the optical rotation values of the studied honeys were ranged from 0.90 to 2.50 . As a matter of fact, the positive rotation values of the studied honeys confirm that all honeys are secretion honeys.

Table 1. Physicochemical analyses of Pine honey from Mugla region.

\begin{tabular}{llll}
\hline \hline & Min & Max & Mean \\
\hline \hline $\begin{array}{l}\text { Specific Optic } \\
\text { rotation }[\alpha]^{20}\end{array}$ & 0,560 & 2.80 & $1,48 \pm 0,76$ \\
\hline Moisture $(\%)$ & 14.00 & 20.30 & $17.50 \pm 2.60$ \\
\hline $\mathrm{Ph}$ & 3.98 & 5.40 & $4.58 \pm 0.70$ \\
\hline
\end{tabular}

It was determined that the moisture amount of the honeys varied between $15 \%$ and $20.30 \%$ and the average value was $17.40 \%$. The moisture values are found suitable with the recommended amount of water in the honey codex (Bogdanov et al, 1999).

It was determined that the $\mathrm{pH}$ values of the studied honeys were ranged from 3.98 to 5.58 and all the honeys had acidic medium. Moreover, the current values found were similar to the honey codex (Bogdanov et al, 1999). Acidic properties of honey earns honey a stronger antibacterial effect and bacteria cannot survive at this $\mathrm{pH}$. It has been reported using capillary electrophoretic technique that gluconic acid, formic, malic, citric and

succinic acids are major acids of honey (Kaygusuz et al. 2016). However, there are phenolic acids in honey, which is higher than these organic acids, and gallic acid, benzoic acid, p-OH benzoic acid, coumaric acid, syringic acid, valinic acid, ferulic acid are important sources of honey (Can et al. 2015; Ertürk, Şahin, Kolaylı \& Ayvaz, 2014; Kolayli et al. 2018).

The biological activity of honey, it consists of phenolic acids and flavonoids. Phenolic content of honey varies according to flora and geographical origin. In this study, total polyphenol values of pine honey were measured spectrophotometrically, and the results were given in Table 2. In general, honeys consist of between 20 and $150 \mathrm{mg}$ gallic acid/100 $\mathrm{g}$ depending on honey species. Total polyphenol contents of the samples were found between 24.60 and $68.20 \mathrm{mg}$ $\mathrm{GAE} / 100 \mathrm{~g}$ of the samples and the mean value was $46.30 \mathrm{mg}$ GAE/100g. All phenolic compounds in honey are measured by the total polyphenol method and phenolic acids, flavonoids, stilbenes, tannins are included in this family (Can, Baltaş, Keskin, Y1ldız \& Kolayl1, 2017). Total flavonoid contents of the honey samples were changed from 0.80 to $2.10 \mathrm{mg} \mathrm{QE} / 100 \mathrm{~g}$. The flavonoids contents of pine honeys were indicated nearly high and the other study findings confirmed this situation (Can et al, 2015; Kolayl1, Baltas, Sahin \& Karaoglu, 2017). 
Table 2. Total phenolic contents of Pine honey from Mugla region.

\begin{tabular}{llll}
\hline \hline & Min & Max & Mean \\
\hline $\begin{array}{l}\text { Total phenolic } \\
\text { content } \\
(\mathrm{mg} \mathrm{GAE} / 100 \mathrm{~g})\end{array}$ & 24.60 & 68.20 & $46.30 \pm 10.30$ \\
& & & \\
\hline Total flavonoid & & & \\
content & 0.80 & 2.10 & $1.46 \pm 0.78$ \\
$(\mathrm{mg} \mathrm{QE} / 100 \mathrm{~g})$ & & & \\
\hline
\end{tabular}

Phenolic profile of the pine honey was determined using nineteen polyphenolic standards with high pressure liquid chromatography (HPLC-UV) (Malkoç, Kara, Özkök, Ertürk \& Kolaylı, 2019a).

The results were summarized in Table 3 . Protocatechuic acid was the major phenolic compound of the studied phenolic compounds, and chyrisin, $\mathrm{p}-\mathrm{OH}$ benzoic acid and catechin are followed them. Haroun et al. (2012) reported that Turkish honeydew honeys (pine and oak) have been shown to contain protocatechuic acid in the range of 1639 to $5986 \mu \mathrm{g} / \mathrm{kg}$ honey. In the current study, protocatechuic acid was identified as the major component. The presence of protocatechuic acid as a major ingredient in pine honey might be considered to use as a characteristic indicator of honey's origin. The concentrations of protocatechuic acid $480.20 \mu \mathrm{g} / \mathrm{kg}$ honey for pine honeys. Another study was found concentrations of protocatechuic acid ranged from 3058 to 5967 $\mu \mathrm{g} / \mathrm{kg}$ honey for pine honeys (Spilioti et al., 2014). Chrysin was observed to be main flavonoid in pine honeys. Chrysin content was found $210.30 \mu \mathrm{g} / 100$ $\mathrm{g}$ in pine honey. In this study was determined that phenolic components were detected in different proportions in pine honey.

Table 3. Phenolic profiles analyses in HPLC-UV of Mugla pine honey $(\mu \mathrm{g} / 100 \mathrm{~g})$

\begin{tabular}{ll}
\hline \hline Phenolic acids & \\
\hline \hline Gallic acid & $33.20 \pm 5.80$ \\
\hline Protocatechuic acid & $480.20 \pm 105.30$ \\
\hline p-OH Benzoic acid & $98.45 \pm 22.08$ \\
\hline Caffeic acid & $28.60 \pm 12.56$ \\
\hline Syringic acid & $24.10 \pm 6.20$ \\
\hline p-Coumaric acid & $17.80 \pm 10.20$ \\
\hline Ferulic acid & $40.66 \pm 4.05$ \\
\hline $\mathrm{t}-$ Cinnamic acid & - \\
\hline Flavonoids & \\
\hline Catechin & $80.20 \pm 14.04$ \\
\hline Epicatechin & $22.07 \pm 2.80$ \\
\hline Rutin & - \\
\hline Myricetin & - \\
\hline Daidzein & - \\
\hline Resveratrol & - \\
\hline Luteolin & $38.50 \pm 12.40$ \\
\hline Hesperetin & $18.06 \pm 3.40$ \\
\hline Chrysin & $210.30 \pm 56.07$ \\
\hline Pinocembrin & $33.60 \pm 4.80$ \\
\hline Caffeic acid phenethyl & $24.50 \pm 8.40$ \\
\hline ester & \\
\hline
\end{tabular}

\section{REFERENCES}

Bahramsoltani, R., Ebrahimi, F., Farzaei, M. H., Baratpourmoghaddam, A., Ahmadi, P., Rostamiasrabadi, P., ... \& Rahimi, R. (2019). Dietary polyphenols for atherosclerosis: A comprehensive review and future perspectives. Critical Reviews In Food Science And Nutrition, 59(1), 114-132.

Bogdanov, S., Lüllmann, C., Martin, P., von der Ohe, W., Russmann, H., Vorwohl, G., ... \& Flamini, C. (1999). Honey quality and international regulatory standards: review by the International Honey Commission. Bee world, 80(2), 61-69.

Can, Z., Baltaş, N., Keskin, S., Yıldız, O., \& Kolayl1, S. (2017). Properties of antioxidant and anti-inflammatory activity and phenolic profiles of Şevketi Bostan (Cnicus benedictus L.) cultivated 
in Aegean Region from Turkey. Turkish Journal of Agriculture-Food Science and Technology, 5(4), 308-314.

Can, Z., Yildiz, O., Sahin, H., Turumtay, E. A., Silici, S., \& Kolayli, S. (2015). An investigation of Turkish honeys: their physico-chemical properties, antioxidant capacities and phenolic profiles. Food Chemistry, 180, 133-141.

Çakır, H. E., Şirin, Y., Kolaylı, S., \& Zehra, C. A. N. (2018). Validation methods for phenolic components with RP-HPLC-UV in various bee products. Apiterapi ve Doğa Dergisi, 1(1), 13-19. Dinkov, D. (2003). A scientific note on the specific optical rotation of three honey types from Bulgaria. Apidologie, 34(3), 319-320.

Ertürk, Ö., Şahin, H., Kolaylı, S., \& Ayvaz, M. Ç. (2014). Antioxidant and antimicrobial activity of East Black Sea Region honeys. Turkish Journal of Biochemistry/Turk Biyokimya Dergisi, 39(1).

Fukumoto, L. R., \& Mazza, G. (2000). Assessing antioxidant and prooxidant activities of phenolic compounds. Journal of Agricultural and Food Chemistry, 48(8), 3597-3604.

Haroun, M. I., Poyrazoglu, E. S., Konar, N., \& Artik, N. (2012). Phenolic acids and flavonoids profiles of some Turkish honeydew and floral honeys. J Food Technol, 10, 39-45.

Joseph, S. V., Edirisinghe, I., \& Burton-Freeman, B. M. (2016). Fruit polyphenols: A review of anti- inflammatory effects in humans. Critical Reviews in Food Science and Nutrition, 56(3), 419-444. Kaygusuz, H., Tezcan, F., Erim, F. B., Yildiz, O., Sahin, H., Can, Z., \& Kolayli, S. (2016). Characterization of Anatolian honeys based on minerals, bioactive components and principal component analysis. LWT-Food Science and Technology, 68, 273-279.

Kim, K. H., Tsao, R., Yang, R., \& Cui, S. W. (2006). Phenolic acid profiles and antioxidant activities of wheat bran extracts and the effect of hydrolysis conditions. Food Chemistry, 95(3), 466-473.

Kolaylı, S., Baltas, N., Sahin, H., \& Karaoglu, S. (2017). Evaluation of anti-Helicobacter pylori activity and urease inhibition by some Turkish authentic honeys. Journal of Food Science and Engineering, 7, 67-73.

Kolayli, S., Can, Z., Çakir, H. E., Okan, O. T., \& Yildiz, O. (2018). An investigation on Trakya region Oak (Quercus spp.) honeys of Turkey: Their physico-chemical, antioxidant and phenolic compounds properties. Turkish Journal of Biochemistry, 43(4), 362-374.

Malkoç, M., Çakır, H., Yakup, K. A. R. A., Zehra, C. A. N., \& Kolayl1, S. (2019b). Phenolic composition and antioxidant properties of Anzer honey from black sea region of Turkey. Uludağ Arıcılık Dergisi, 19(2), 143-151. 
Malkoç, M., Yakup, K. A. R. A., Özkök, A., Ertürk, Ö., \& Kolaylı, S. (2019a). Karaçalı (Paliurus Spina-Christi Mill.) Balının Karakteristik Özellikleri. Uludağ Arıcılık Dergisi, 19(1), 69-81.

Özkök, D., \& Silici, S. (2017). Antioxidant activities of honeybee products and their mixtures. Food Science and Biotechnology, 26(1), 201-206.

Serrano, S., Rodríguez, I., Moreno, R., \& Rincón, F. (2019). Detection of key factors affecting specific optical rotation determination in honey. CyTA-Journal of Food, 17(1), 574-580.

Singleton, V. L., Orthofer, R., \& LamuelaRaventós, R. M. (1999). Analysis of total phenols and other oxidation substrates and antioxidants by means of folin-ciocalteu reagent. In Methods in Enzymology (Vol. 299, pp. 152-178). Academic press.

Spilioti, E., Jaakkola, M., Tolonen, T., Lipponen, M., Virtanen, V., Chinou, I., ... \& Moutsatsou, P. (2014). Phenolic acid composition, antiatherogenic and anticancer potential of honeys derived from various regions in Greece. Plos One, 9(4).

Kara, Y., Can, Z., \& Kolaylı, S. (2019). HPLC analyses of polyphenolic compounds in oak (Querces frainetto) honey from Kırklareli region of Turkey. Turkish Journal of Analytical Chemistry, 1. 